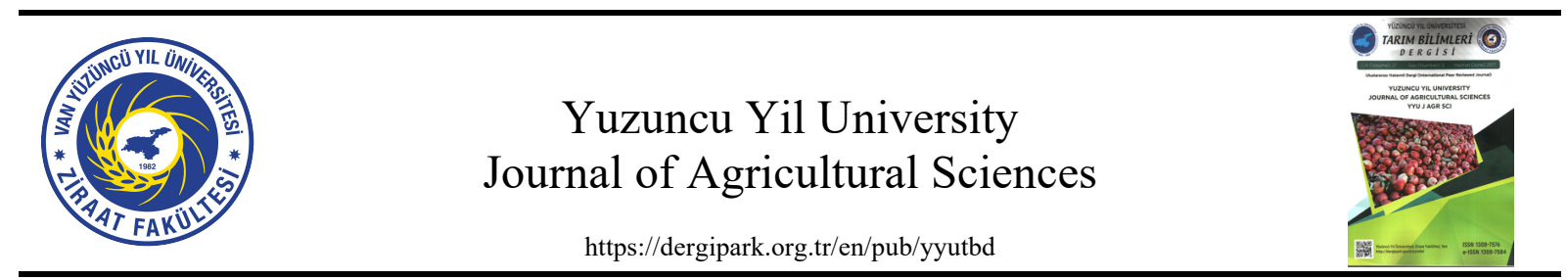

Research Article

\title{
Determination of Nut Characteristics and Biochemical Components of Some Pecan Nut Cultivars
}

\author{
Rabia YILMAZ ${ }^{1}$, Adnan Nurhan YILDIRIM*², Civan ÇELİK ${ }^{3}$, Yaşar KARAKURT ${ }^{4}$ \\ ${ }^{1,2}$ Isparta University of Applied Sciences, Faculty of Agriculture, Department of Horticulture, 32200 Isparta, \\ Turkey \\ ${ }^{3,4}$ Isparta University of Applied Sciences, Faculty of Agriculture, Department of Agriculture Biotechnology, \\ 32200 Isparta, Turkey
}

${ }^{1}$ https://orcid.org/0000-0003-0980-2619 ${ }^{2}$ https://orcid.org/0000-0003-2526-040X ${ }^{3}$ https://orcid.org/0000-0002-1696-5902 ${ }^{4}$ https://orcid.org/0000-0003-3914-0652

*Corresponding author e-mail: adnanyildirim@isparta.edu.tr

\section{Article Info}

Received: 19.03 .2021

Accepted: 09.09.2021

Online Published: 15.12 .2021

DOI: $10.29133 /$ yyutbd. 899879

Keywords

Antioxidant, Carya illinoensis, Kernel percentage, Total flavonoid, Total oil.

\begin{abstract}
This study was carried out to determine some fruit properties and biochemical (total oil, fatty acid composition, protein, total phenolic compounds, total antioxidant capacity, total flavonoids) characteristics of different pecan nut cultivars (Burkett, Choctaw, Mahan, Western, Wichita) grown in the Antalya Region (BATEM). It was determined that some fruit properties and biochemical contents of the cultivars used in the study. In the study, it was determined that the shelled fruit weight varied between $7.78 \mathrm{~g}$ (Burkett) and $11.40 \mathrm{~g}$ (Mahan), kernel weight between $3.45 \mathrm{~g}$ (Burkett) and $5.99 \mathrm{~g}$ (Mahan), and kernel percentage between 44.2\% (Burkett) and 55.6\% (Western). The total oil content of the cultivars ranged from $67.70 \%$ (Mahan) to $73.95 \%$ (Wichita), protein content from $7.45 \%$ (Mahan) to $9.76 \%$ (Western), total phenolic compounds from $115.29 \mathrm{mg}$ $\mathrm{GAE} \mathrm{g}^{-1}$ (Choctaw) to $176.65 \mathrm{mg} \mathrm{GAE} / \mathrm{g}$ (Burkett), total antioxidant capacity from $201.36 \mathrm{mg} \mathrm{TEAC} \mathrm{g}^{-1}$ (Choctaw) to $487.89 \mathrm{mg} \mathrm{TEAC} \mathrm{g}^{-1}$ (Burkett), and total flavonoids from $1.84 \mathrm{mg}$ Catechin $\mathrm{g}^{-1}$ (Western) to $2.24 \mathrm{mg}$ Catechin $/ \mathrm{g}$ (Mahan). In the study, oleic acid was determined as the major fatty acid, and the lowest ratio of unsaturated fatty acids was found in the Wichita cultivar (90.73\%), but the highest ratio was determined in the Western cultivar (91.43\%).
\end{abstract}

\section{Bazı Pikan Ceviz Çeşitlerinin Meyve Özellikleri İle Biyokimyasal İçeriklerinin Belirlenmesi}

\section{Makale Bilgileri}

Geliş: 19.03.2021

Kabul: 09.09.2021

Online Yayınlanma: 15.12.2021

DOI: $10.29133 /$ yyutbd.899879

\section{Anahtar Kelimeler}

Antioksidan,

Carya Illinoensis,

İç oranı,

Toplam flavonoid,

Toplam yağ.
Öz: Bu çalışma Antalya ekolojisinde (BATEM) yetişen pikan çeşitlerine ait (Burkett, Choctaw, Mahan, Western, Wichita) bazı meyve özellikleri ile bazı biyokimyasal özelliklerini (toplam yağ, yağ asitleri kompozisyonu, protein oranları, toplam fenolik madde içerikleri, toplam antioksidan kapasiteleri, toplam flavonoid içerikleri) belirlemek için yapılmıştır. Araştırmada kullanılan çeşitlerin bazı meyve özellikleri ile biyokimyasal içerikleri belirlenmiştir. Araştırmada kabuklu meyve ağırlıklarının $7.78 \mathrm{~g}$ (Burkett)-11.40 g (Mahan), iç meyve ağırlıklarının $3.45 \mathrm{~g}$ (Burkett)-5.99 g (Mahan), iç oranının \% 44.2 (Burkett)\% 55.6 (Western) arasında değişiklik gösterdiği belirlenmiştir. Çeşitlere ait toplam yağ içerikleri \%67.70 (Mahan)-\%73.95 (Wichita), protein oranı \% 7.45 (Mahan)-\% 9.76 (Western), toplam fenolik madde içeriği $115.29 \mathrm{mg} \mathrm{GAE} / \mathrm{g}$ (Choctaw)-176.65 mg GAE/g (Burkett), toplam antioksidan kapasitesi $201.36 \mathrm{mg}$ 
TEAC/g (Choctaw)-487.89 mg TEAC/g (Burkett), toplam flavonoid içeriği ise $1.84 \mathrm{mg}$ Catechin/g (Western)-2.24 mg Catechin/g (Mahan) arasında değişmiştir. Araştırmada oleik asit majör yağ asidi olarak öne çıkmış, doymamış yağ asitleri oranı en düşük Wichita çeşidinde (\% 90.73), en yüksek Western çeşidinde (\% 91.43) saptanmıştır.

\section{Introduction}

Although the homeland of Pecan nut [Carya illinoinensis (Wangenheim.) K. Koch] is North America, it is cultivated nowadays in different regions of the world such as Mexico, South Africa, Australia, China, and Turkey (Gardea et al., 2011; Rosa et al., 2014). The amount of pecan nut production was 222000 tons in the United States, which was the world's largest pecan nut producer in 2019, followed by Mexico (128 705 tons), South Africa (18 945 tons), Australia (2 900 tons), and Turkey (2 000 tons) (INC., 2018).

The studies related to the pecan nut were started with the introduction of 14 cultivars in 1969 by the Western Mediterranean Agricultural Research Institute (Tuzcu and Yildirim, 2000). Moreover, determining the tree growth, fruit characteristics, and biochemical contents of these cultivars have gained importance in terms of improving the cultivation of pecan nuts. Nowadays, the preference for products with high nutritional content by the consumers and products with high yields by the producers demonstrate that the demand for pecan nuts is increasing day by day. Thus, the widespread increasing cultivation of pecan nut in countries other than the USA is considered as an indicator that its production will increase in the coming years. In addition, the high internal yield, high internal quality, high adaptability to poor soils, the easily breakable characteristic of its crust by hand, the long time postharvest storage ability of its fruits and its ability to be cultivated with less cost in the subtropical climates as compared to the other fruit species are the most important characteristics of pecan nut which distinguish it from other hard-shelled fruit species (Ozdemir, 2013).

Pecan nut has also been reported in the previous studies that hard-shelled fruits reduce the risk of cardiovascular diseases due to their high content of unsaturated fatty acids, have effects such as lowering cholesterol and stress, give more calories than other hard-shelled fruits, and are richer in vitamin B1 and C and especially vitamin E (Ozer and Güven, 2008). In addition, the pecan nut has been reported as a fruit that has the ability to reduce the incidence of chronic diseases such as Alzheimer, Parkinson and some cancer diseases (Mertens-Talcott and Percival, 2005). Moreover, the pecan nut is rich in terms of sterols and tocopherols, which are described as bioactive molecules in hard-shelled fruits and is also considered as an alternative product due to its natural antioxidant activity (Prado et al., 2009). Natural antioxidants have the ability to protect against free radical damage to fats, proteins, carbohydrates, and even DNA (Robbins et al., 2015). It has also been stated in the previous studies that the criteria such as location, soil characteristics, cultivar, harvest maturity, cultural practices, and ecological factors have an effect on the biochemical contents of the fruits, such as fat content, phenolic compounds, and antioxidant activity (Rosa et al., 2011).

The aim of the current study was to determine some fruit properties and biochemical (total oil, fatty acid composition, protein, total phenolic compounds, total antioxidant capacity, total flavonoids) characteristics of different pecan nut cultivars (Burkett, Choctaw, Mahan, Western, Wichita) grown in the Antalya Region (BATEM).

\section{Materials and Methods}

\subsection{Materials}

Some pecan nut cultivars (Burkett, Choctaw, Mahan, Western, Wichita) obtained from the Kayaburnu Fruit Production Station of Antalya Western Mediterranean Agricultural Research Institute that were planted at approximately $12 \times 12 \mathrm{~m}$ intervals and collected from the trees of full yield age, were used in the study. 


\subsection{Methods}

\subsubsection{Physical Measurements}

Within the scope of the study, the shell fruit weights and internal fruit weights of the selected pecan nuts were determined as " $\mathrm{g}$ " by weighing and averaging them on a sensitive electronic scale with a sensitivity of $0.01 \mathrm{~g}$. The internal ratio was determined as "\%" by dividing the internal weights of the nuts by the fruit weight and multiplying by 100 ( Sen, 1980).

\subsubsection{Biochemical Analyses}

The harvested nuts for analysis were shelled, the edible parts were dried in a laboratory-type hot air drying oven up to a constant weight at $40{ }^{\circ} \mathrm{C}$ and ground with the help of a knife grinder. In the study, the fruits of 30 years old and full-yield age trees of some pecan nut cultivars (Burkett, Choctaw, Mahan, Western, Wichita) grown in the Western Mediterranean (Antalya) ecology were used. The measurements examined were carried out on three fruits for each cultivar with three replications. The following biochemical analyzes were carried out on the fruits obtained from five pecan nut cultivars.

\subsubsection{Lipid Rate}

The lipid analyses of the nut samples were performed by reading as $\%$ in a Nuclear Magnetic Resonance (NMR) device. The seeds were kept in the oven set at $70{ }^{\circ} \mathrm{C}$ for 48 hours, evaporated, and 2 $\mathrm{g}$ of moisture were weighed, and the average oil ratio was calculated by three readings in each parcel on the NMR device (Erbas et al., 2016).

\subsubsection{Fatty Acids Composition}

The fatty acid composition was determined by using the gas chromatography (Shimadzu GC2025) device with flame ionization detector (FID) located at the Innovative Technologies Research and Application Center in Isparta. $2 \mathrm{~g}$ of dried ground pecan nuts were subjected to the cold extraction with hexane and the crude oil obtained after the solvent mixture was evaporated, was converted into methyl esters (FAME) with $0.5 \%$ Sodium Methylate (NaoMe) by the method recommended by AOAC. The $\%$ ratios of palmitic $\left(\mathrm{C}_{16}: 0\right)$, stearic $\left(\mathrm{C}_{18}: 0\right)$, oleic $\left(\mathrm{C}_{18}:{ }_{1}\right)$, and linoleic $\left(\mathrm{C}_{18}:{ }_{2}\right)$ fatty acids were determined by obtaining the fatty acids chromatograms. The operating conditions of the $\mathrm{GC}$ device were as follows; Column Teknokroma TR-CN100 $(100 \mathrm{~m} \times 0.25 \mathrm{~mm}, 0.20 \mu \mathrm{m})$, injector temperature $250{ }^{\circ} \mathrm{C}$, detector temperature $250{ }^{\circ} \mathrm{C}$, flow rate (psi) 10 , carrier gas $\mathrm{N}\left(40 \mathrm{ml} \mathrm{min}^{-1}\right)$, injector capacity $1.0 \mu 1$. After waiting 10 minutes at $140{ }^{\circ} \mathrm{C}$, the oven temperature reached $240{ }^{\circ} \mathrm{C}$ with an increase of $3{ }^{\circ} \mathrm{C}$ per minute and incubated at this temperature for 10 minutes. The peaks obtained in the chromatograms were named according to the commercial standard fatty acid methyl ester mixture (Baydar and Erbas, 2014).

\subsubsection{Protein Ratio}

Protein ratio (\%): The protein ratios in pecan nut fruits were obtained according to the nitrogen determination. Nitrogen determination was accomplished by the Kjeldahl distillation method. The basis of the Kjeldahl method in order to determine the total $\mathrm{N}$ content is to convert the nitrogen $(\mathrm{N})$ in the wet-burned plant sample with $\mathrm{H}_{2} \mathrm{SO}_{4}$ to the form of $\mathrm{NH}_{4}-\mathrm{N}$. The amount of $\mathrm{NH}_{3}$ released as a result of the distillation performed in an alkaline environment was captured with the boric acid (Bremner, 1965). According to the Kjeldahl method, $0.5 \mathrm{~g}$ of the samples were placed in a Kjeldahl flask, and $15 \mathrm{ml}$ of $\mathrm{H}_{2} \mathrm{SO}_{4}$ and 1 Kjeldahl tablet (a tablet containing selenium mixtures and $\mathrm{K}_{2} \mathrm{SO}_{4}$ ) were added to the flasks. The balloons were placed in the nitrogen burning device, burned up to $405{ }^{\circ} \mathrm{C}$, and allowed to cool after the burning process (Bayrakli, 1987). The amount of nitrogen (\%) was determined by substituting the amount of acid used as a result of the titration in the formula (Kacar and Inal, 2008). 


\subsubsection{Total Phenolics Content}

Total phenolic content was determined using the Folin Ciocalteau method as reported by Singleton and Rossi (1965). The results were expressed as mg equivalent of gallic acid (GAE) per gram. The basic principle of this method is based on a redox reaction in which phenolic compounds degrade the Folin-Ciocalteu reagent in an alkaline environment and transform themselves into an oxidized form (Singleton and Rossi 1965). The results were calculated according to the gallic acid standard and expressed as $\mathrm{mg} / \mathrm{g}$. Three repetitive readings were done for each sample.

\subsubsection{Total Antioxidant Capacity}

Total antioxidant capacity (mg TEAC $\left.\mathrm{g}^{-1}\right)$ : It was made using DPPH (1,1-diphenyl-2picrylhydrazyl) as reported by Kumaran and Karunakaran (2006). 2 grams of samples were ground and kept at $-20^{\circ} \mathrm{C}$ for 2 hours in $20 \mathrm{~mL}$ of $80 \%$ ethanol. Then it was centrifuged at $2000 \mathrm{rpm}$ for 5 minutes, and the supernatant portion was taken for the analysis. $2 \mathrm{~mL}$ of $0.1 \mathrm{mM}$ DPPH dissolved in methanol was added to $100 \mu \mathrm{L}$ of supernatant. After 30 minutes of incubation, readings were done against methanol at $517 \mathrm{~nm}$. Three repetitions were made for each example.

\subsubsection{Total Flavonoid Content}

Total flavonoid content was determined as described by Kim et al. (2003). For this purpose, 200 $\mathrm{mg}$ of nut sample was added to $10 \mathrm{ml}$ of $80 \%$ methanol and homogenized with a homogenizer. Then it was mixed in a shaking incubator for 15 minutes at room temperature. After centrifugation at $4000 \times \mathrm{rpm}$ for 10 minutes at $40^{\circ} \mathrm{C}$, the supernatant was separated, and then $80 \%$ methanol was added to the remaining pellet and mixed again in the shaking incubator for 10 minutes. After centrifuging at $9000 \times \mathrm{rpm}$ for 10 minutes, the supernatant was filtered and kept at $+4{ }^{\circ} \mathrm{C}$ in a refrigerator until it was used for the analysis. Each sample was taken into $1 \mathrm{~mL}$ glass tubes, and $0.3 \mathrm{~mL}$ of $5 \% \mathrm{NaNO}_{2}$ solution was added and mixed. After 5 minutes of incubation, the samples were centrifuged at $4000 \mathrm{rpm}$ for five minutes, and the supernatant was separated, and $0.3 \mathrm{ml}$ of $10 \% \mathrm{AlCl}_{3}$ has added again to the remaining pellet. After incubation for six more minutes, $2 \mathrm{ml}$ of $1 \mathrm{M} \mathrm{NaOH}$ was added, mixed, and incubated for 2 minutes. Then, $4 \mathrm{~mL}$ of pure water was added and mixed thoroughly, and the absorbance values of the samples were read at $510 \mathrm{~nm}$ wavelength. The analyses were carried out with three replications for each sample.

\subsubsection{Statistical Analysis}

The study was carried out on five pecan nut cultivars with three replications and two analyses per replication. Twenty fruits were used for each replication. The obtained data were subjected to the variance analysis using the SAS statistical package program (Version 6.12, SAS Institute, Cary, NC, USA). The differences between the means were determined using the Duncans multiple range test.

\section{Results}

In the study, significant differences were obtained between the cultivars in terms of nut weight, kernel weight, and kernel ratio. Mahan cultivar had the highest value as $11.40 \mathrm{~g}$ among the cultivars. This was followed by Choctaw with $10.54 \mathrm{~g}$, Wichita with $8.24 \mathrm{~g}$, and Western cultivars with $7.96 \mathrm{~g}$. The lowest nut weight was obtained in the Burkett cultivar with $7.78 \mathrm{~g}$. The highest kernel weight (5.99) was obtained from the Mahan cultivar, which was followed by Choctaw with $5.50 \mathrm{~g}$, Wichita with 4.59 $\mathrm{g}$, and Western cultivars with $4.43 \mathrm{~g}$, respectively. The lowest kernel weight was obtained from Burkett cultivar with $3.45 \mathrm{~g}$. The highest kernel ratio was obtained in the Western and Wichita cultivars as 55.60 $\%$, followed by Mahan with $52.30 \%$ and Choctaw with $52.20 \%$, respectively. In the study, the lowest kernel ratio was found in the Burkett cultivar as $44.20 \%$ (Table 1). 
Table 1. Pomological measurements of pecan nut cultivars

\begin{tabular}{lccc}
\hline Cultivar & Nut Weight $(\mathrm{g})$ & Kernel Weight $(\mathrm{g})$ & Kernel Ratio (\%) \\
\hline Burket & $7.78^{\mathrm{b}}$ & $3.45^{\mathrm{c}}$ & $44.17^{\mathrm{b}}$ \\
Choctaw & $10.54^{\mathrm{a}}$ & $5.50^{\mathrm{ab}}$ & $52.17^{\mathrm{a}}$ \\
Mahan & $11.40^{\mathrm{a}}$ & $5.99^{\mathrm{a}}$ & $52.33^{\mathrm{a}}$ \\
Western & $7.96^{\mathrm{b}}$ & $4.43^{\mathrm{bc}}$ & $55.63^{\mathrm{a}}$ \\
Wichita & $8.24^{\mathrm{b}}$ & $4.59^{\mathrm{bc}}$ & $55.63^{\mathrm{a}}$ \\
\hline
\end{tabular}

*The difference between the means shown by different letters in the same column is statistically significant $(\mathrm{p} \leq 0.05)$.

Some total fat content (TFC) and fatty acid composition, and biochemical contents of the pecan nut cultivars are given in Table 2 and Table 3 . In the study, significant differences were found between the cultivars in terms of stearic acid, oleic acid, linoleic acid, protein ratios, and total antioxidant capacity, while there were no significant differences between the cultivars in terms of palmitic acid, saturated fatty acids, unsaturated fatty acid, total phenolics, and total flavonoid contents. The highest TFC was obtained in the Wichita cultivar $(73.95 \%)$, which was followed by the Burkett $(71.00 \%)$, Choctaw (70.45\%) varieties, respectively. In the study, the highest stearic acid was obtained in Wichita (2.99) and Mahan (2.93) cultivars. The highest oleic acid was determined Choctaw (71.68), while the highest linoleic acid Western cultivar with 29.81. The highest protein content was obtained in the Western cultivar (9.76\%), which was followed by the Wichita (9.72\%), Choctaw (9.65\%), and Burkett $(9.64 \%)$ cultivars, respectively. The lowest protein ratio was obtained in the Mahan cultivar with $7.45 \%$. In the study, the highest total phenolic substance content was obtained in the Burkett cultivar with 176.65 mg GAE g ${ }^{-1}$, which was followed by Wichita with $167.91 \mathrm{mg} \mathrm{GAE} \mathrm{g}^{-1}$, Western with $140.89 \mathrm{mg}^{\mathrm{GAE}}$ $\mathrm{g}^{-1}$, and Mahan with $130.75 \mathrm{mg} \mathrm{GAE} \mathrm{g}^{-1}$, respectively. The lowest total phenolic substance content was obtained in the Choctaw cultivar with $115.29 \mathrm{mg} \mathrm{GAE} \mathrm{g}^{-1}$. The highest total antioxidant capacity was obtained in the Burkett cultivar with $487.89 \mathrm{mg} \mathrm{TEAC} \mathrm{g}^{-1}$, followed by the Wichita with $447.08 \mathrm{mg}$

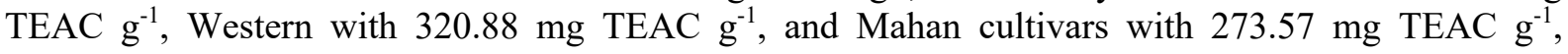
respectively. The lowest total antioxidant capacity was obtained in the Choctaw cultivar with $201.36 \mathrm{mg}$ TEAC/g. The highest total flavonoid content was obtained in the Mahan cultivar with $2.24 \mathrm{mg}$

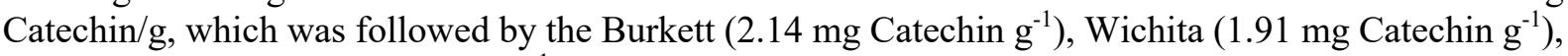
and Choctaw (1.85 mg Catechin $\mathrm{g}^{-1}$ ) cultivars. The lowest total flavonoid content was obtained in the Western cultivar with $1.84 \mathrm{mg}^{\text {Catechin }} \mathrm{g}^{-1}$.

Table 2. Total fat content and fatty acid composition of pecan nut cultivars

\begin{tabular}{lcllll}
\hline Cultivars & ${ }^{1}$ TFC $(\%)$ & $\begin{array}{l}\text { Palmitic acid } \\
\left(\mathrm{C}_{16}: 0\right)\end{array}$ & $\begin{array}{l}\text { Stearic acid } \\
\left(\mathrm{C}_{18}: 0\right)\end{array}$ & $\begin{array}{l}\text { Oleic acid } \\
\left(\mathrm{C}_{18}: 1\right)\end{array}$ & $\begin{array}{l}\text { Linoleic acid } \\
\left(\mathrm{C}_{18}: 2\right)\end{array}$ \\
\hline Burkett & $71.00 \pm 0.1^{\mathrm{b}}$ & $5.54 \pm 0.1$ & $2.41 \pm 0.08^{\mathrm{c}}$ & $69.63 \pm 0.50^{\mathrm{b}}$ & $21.48 \pm 0.63^{\mathrm{c}}$ \\
Choctaw & $70.45 \pm 0.7^{\mathrm{c}}$ & $5.69 \pm 0.1$ & $2.45 \pm 0.10^{\mathrm{c}}$ & $71.68 \pm 0.43^{\mathrm{a}}$ & $18.87 \pm 0.39^{\mathrm{d}}$ \\
Mahan & $67.70 \pm 0.4^{\mathrm{c}}$ & $5.38 \pm 0.05$ & $2.93 \pm 0.12^{\mathrm{ab}}$ & $66.35 \pm 0.40^{\mathrm{c}}$ & $23.94 \pm 0.18^{\mathrm{b}}$ \\
Western & $68.45 \pm 0.7^{\mathrm{c}}$ & $5.67 \pm 0.22$ & $2.74 \pm 0.05^{\mathrm{b}}$ & $60.17 \pm 0.86^{\mathrm{d}}$ & $29.81 \pm 0.83^{\mathrm{a}}$ \\
Wichita & $73.95 \pm 0.6^{\mathrm{a}}$ & $5.53 \pm 0.15$ & $2.99 \pm 0.03^{\mathrm{a}}$ & $69.73 \pm 0.31^{\mathrm{b}}$ & $19.99 \pm 0.03^{\mathrm{d}}$ \\
\hline
\end{tabular}

*The difference between the means shown by different letters in the same column is statistically significant $(\mathrm{p} \leq 0.05)$.

${ }^{1}$ TFC (Total Fat Content).

Table 2. Total fat content and fatty acid composition of pecan nut cultivars (continued)

\begin{tabular}{|c|c|c|c|c|}
\hline Cultivars & $\begin{array}{l}\text { Linolenic acid } \\
\left(\mathrm{C}_{18: 3}\right)\end{array}$ & $\begin{array}{c}\text { Saturated Fatty Acids } \\
\text { (SFA) }\end{array}$ & Unsaturated Fatty Acids (UFA) & UFA/SFA \\
\hline Burkett & $0.31 \pm 0.02^{\mathrm{b}}$ & 7.95 & 91.42 & 11.49 \\
\hline Choctaw & $0.51 \pm 0.08^{b}$ & 8.14 & 91.06 & 11.18 \\
\hline Mahan & $0.90 \pm 0.07^{\mathrm{a}}$ & 8.31 & 91.19 & 10.97 \\
\hline Western & $1.15 \pm 0.19^{\mathrm{a}}$ & 8.41 & 91.13 & 10.83 \\
\hline Wichita & $1.01 \pm 0.02^{\mathrm{a}}$ & 8.52 & 90.73 & 10.65 \\
\hline
\end{tabular}


Table 3. Some biochemical properties of pecan nut cultivars

\begin{tabular}{lllll}
\hline Cultivars & $\begin{array}{l}{ }^{1} \text { PR } \\
(\%)\end{array}$ & $\begin{array}{l}{ }^{2} \text { TPSC } \\
\left(\mathrm{mg} \mathrm{GAE} \mathrm{g}^{-1}\right)\end{array}$ & $\begin{array}{l}{ }^{3} \mathrm{TAC} \\
(\mathrm{mg} \mathrm{TEAC} \mathrm{g}\end{array}$ & $\begin{array}{l}{ }^{-1} \text { TFC } \\
\left(\mathrm{mg} \mathrm{Catechin}^{-1}\right)\end{array}$ \\
\hline Burkett & $9.64 \pm 0.59^{\mathrm{a}}$ & $176.65 \pm 36.93$ & $597.21 \pm 183.41^{\mathrm{a}}$ & $2.14 \pm 0.05$ \\
Choctaw & $9.65 \pm 0.63^{\mathrm{a}}$ & $115.29 \pm 31.84$ & $256.02 \pm 157.78^{\mathrm{d}}$ & $1.85 \pm 0.27$ \\
Mahan & $7.45 \pm 1.36^{\mathrm{b}}$ & $130.75 \pm 35.76$ & $455.77 \pm 41.97^{\mathrm{b}}$ & $2.24 \pm 0.22$ \\
Western & $9.76 \pm 0.41^{\mathrm{a}}$ & $140.89 \pm 27.74$ & $393.76 \pm 14.04^{\mathrm{bc}}$ & $1.84 \pm 0.22$ \\
Wichita & $9.72 \pm 0.06^{\mathrm{a}}$ & $167.91 \pm 54.45$ & $360.24 \pm 53.56^{\mathrm{c}}$ & $1.91 \pm 0.11$ \\
\hline
\end{tabular}

*The difference between the means shown by different letters in the same column is statistically significant ( $\mathrm{p} \leq 0.05)$.

${ }^{1} \mathrm{PR}$ (Protein Content), ${ }^{2} \mathrm{TPSC}$ (Total Phenolic Substance Content), ${ }^{3}$ TAC (Total Antioxidant Capacity), ${ }^{4}$ TFC (Total Flavonoid Content)

\section{Discussion}

Similar to our results, Zhang and Duan et al. (2011) determined that although the protein contents of the Jinhua and Shaoxing cultivars varied over the years, the protein ratios varied between $8.50 \%-9.70 \%$ in the Jinhua cultivar and between $7.50 \%-8.30 \%$ in the Shaoxing cultivar. However, Wakeling et al. (2001) have found protein ratios of $4.91 \%$ and $5.08 \%$ in the Wichita and Western Schley cultivars, respectively, which are the prominent cultivars cultivated in Australia. Venkatachalam et al. (2007) reported that the protein contents of the cultivars varied between $6.00 \%$ and $11.29 \%$, and the geographical differences (soil properties, altitude, etc.) in the growing regions had significant effects on the biochemical contents of the seeds. Poletto et al. (2020) stated that the protein ratios in pecan nut genotypes varied between $6.90 \%$ and $17.40 \%$, and these differences might be caused by both the environmental effects and genetic differences. Ortiz-Quezada et al. (2011) have reported that pecan nut seeds are rich in proteins, mineral substances, oils, and vitamins, and they contain an average of $9.00 \%$ protein according to USDA. However, they have reported that pecan nuts seeds may exhibit allergic effects for sensitive people, and proteins with allergen effects are characterized by the genes A $2 \mathrm{~S}$ albümin and Car i1 and that these genes can become more active during the storage period or under heat treatment. Elmore and Polles (1980) applied different doses of ammonium nitrate to trees in the desirable pecans cultivar in their study and found that it increased the amounts of glutamate and proline. In addition, they also reported that the treatments caused the differences in the enzyme sequences including lysine, arginine, aspartate, serine, alanine, cysteine, valine, isoleucine, leucine, and tyrosine.

Similar to our findings, Flores Estrada et al. (2020) reported that the total phenolic substance contents varied between $87.61 \mathrm{mg} \mathrm{GAE} \mathrm{g}^{-1}$ (Wichita) and $102.78 \mathrm{mg} \mathrm{GAE} / \mathrm{g}$ (Western). Moreover, the researchers stated that the total amount of phenolic substances is one of the most important biochemical parameters determining the quality of pecan nuts. Similarly, Villarreal-Lozoya et al. (2007) found that the total phenolic substance contents ranged from $70.00 \mathrm{mg} \mathrm{GAE} \mathrm{g}^{-1}$ to $106.00 \mathrm{mg} \mathrm{GAE} \mathrm{g}^{-1}$. They also stated that the cultivation methods have significant effects on the biochemical contents of the cultivars. Prado et al. (2009) reported that the total phenolic substance contents varied between $117 \mathrm{mg} \mathrm{GAE} \mathrm{g}^{-1}$ and $167 \mathrm{mg} \mathrm{GAE} \mathrm{g}^{-1}$, which is higher than our results. In their study investigating the effects of different pruning methods on the bioactive substances contained in the seed, Heerema et al. (2014) arranged the crown heights to be 1.50-3.00 m, 3.00-4.50 m, and 4.50-6.00 m, and they obtained the highest total material content in the trees with a high crown. As a result, they reported that there was a positive relationship between the total phenolic substance content and exposure to light. Ortiz-Quezada et al. (2011) reported that the total amount of phenolic substances contained in the pecan nuts is higher than that of other hard-shelled fruits and has a protective effect against atherosclerosis, hypertension, cardiovascular diseases, cancer, and viral infections in the human body. Alasavar and Bolling (2015) have stated that the total phenolic content of pecans varied between $1284.00 \mathrm{mg}$ GAE $100 \mathrm{~g}^{-1}$ and 2016 mg GAE $100 \mathrm{~g}^{-1}$, and these differences may vary according to the factors such as cultural processes, ecological conditions, and genetic characteristics. The researchers have stated that these differences obtained in the total phenolic contents of the cultivars can vary according to the genetic characteristics of the cultivar, together with the ecological factors during the harvest years, especially the temperature, maturity, cultural processes, and breeding techniques. Jia et al. (2018) found that the total phenolic substance contents of the seeds changed in the different stages of the development and reached the highest values during the developmental stage of the seed, but rapidly decreased to the lowest value 
when the seed reached a milky white color. Additionally, they also reported that the differences in the total phenolic contents of the cultivars might be caused by the ecological differences and breeding techniques. Rosa et al. (2011) have stated that the total phenolic substance contents vary according to the location, and the phenolic substances are generally more synthesized when the plants are exposed to the biotic and abiotic stress conditions, and therefore, their concentrations are mainly dependent on the environmental conditions and then cultural practices, including temperature and postharvest applications. Kornsteiner et al. (2006) stated that the total phenolic substance contents in hard-shelled fruits differed according to the species and varied between $32.00 \mathrm{mg} \mathrm{GAE} 100 \mathrm{~g}^{-1}$ fresh weight (pine nuts) and $1625.00 \mathrm{mg}$ GAE $100 \mathrm{~g}^{-1}$ fresh weight. Researchers have reported that the hard-shelled fruits have an important place in human nutrition due to their high contents of fat, phenolic substances, energy, and antioxidants, and that pecan nuts and pistachios contain higher total phenolics than others. Turgut et al. (2020) reported that the total amount of phenolic substances varied between $372.94 \mathrm{mg}$ GAE 100 $\mathrm{g}^{-1}$ (Tejas) and $1271.00 \mathrm{mg}$ GAE $100 \mathrm{~g}^{-1}$ (Shoshomi).

Prado et al. (2013) stated that the total amount of antioxidants is $1467.90 \mu \mathrm{mol} \mathrm{TEAC/g}$ in the cultivars, and the differences between the cultivars may be due to the genetic characteristics, soil conditions, ecological characteristics, maturity period, and growing conditions. Similar to our findings, Lombardini et al. (2009) reported that the antioxidant capacities showed a great variation among pecan

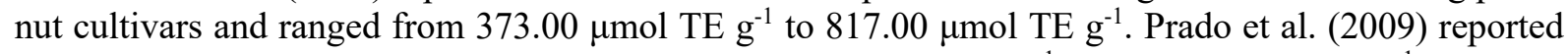
that the antioxidant capacities varied between $385.00 \mathrm{mg}$ TEAC g $^{-1}$ and $572 \mathrm{mg}$ TEAC g${ }^{-1}$. MedinaJuarez et al. (2018) stated that the total antioxidant capacities were between $243.45 \mu \mathrm{M} \mathrm{TE} \mathrm{g}{ }^{-1}$ and $287.67 \mu \mathrm{M} \mathrm{TE} \mathrm{g}^{-1}$, and the antioxidant capacities varied depending on the variation and concentration of phenolic compounds. Villarreal-Lozoya et al. (2007) stated that the antioxidant capacities ranged from $331.00 \mathrm{mg} \mathrm{TE} \mathrm{g}^{-1}$ (Kiowa) to $675.00 \mathrm{mg} \mathrm{TE} \mathrm{g}^{-1}$ (Kanza), and the variations between the cultivars might be affected by the genetic characteristics, maturity, ecological factors, and storage conditions. Robbins et al. (2015) reported that the antioxidant capacities varied between 13.50 mmol Trolox eq 100 $\mathrm{g}^{-1}$ and $25.50 \mathrm{mmol}$ Trolox eq $100 \mathrm{~g}^{-1}$, and this change might result from the harvest year, location, maturity, genetic characteristics, cultural practices, and especially fertilization. Heerema et al. (2014), arranged the crown heights to be 1.50-3.00 m, 3.00-4.50 m, and 4.50-6.00 m, and they did not determine significant differences between the crown heights and total antioxidant capacities and that there was no positive relationship between antioxidant capacity and crown height. Turgut et al. (2020) reported that their total antioxidant capacity ranged from $26.21 \mathrm{mmol} \mathrm{TE} \mathrm{g}^{-1}$ to $147.93 \mathrm{mmol} \mathrm{TE} \mathrm{g}^{-1}$. However, they stated that the correlation between the phenolic and flavonoid contents of pecan nut and its antioxidant activity was high.

Rosa et al. (2011) found that the total flavonoid contents in the peel and fruit varied as $26.30 \mathrm{mg}$ $\mathrm{g}^{-1}$ fresh weight-36.10 mg g${ }^{-1}$ fresh weight, $5.80 \mathrm{mg} \mathrm{g}^{-1}$ fresh weight-6.40 mg g $\mathrm{mg}^{-1}$ fresh weight respectively, and they contained more total flavonoids in the peel as compared to the fruit. Moreover, the researchers stated that the total flavonoid concentrations could change with the cultural practices, temperature, and postharvest applications. Medina-Juarez et al. (2018) stated that the total flavonoid contents were between $13.34 \mathrm{mg} \mathrm{CE} \mathrm{g}^{-1}$ and $16.36 \mathrm{mg} \mathrm{CE} \mathrm{g}^{-1}$, and the antioxidant capacity varied depending on the variation and concentration of intrinsic phenolic compounds. Jia et al. (2018) found that the total flavonoid content varied in the different growth stages of the seed, and the total flavonoid content reached the highest value at the stage when the seed reached a milky white color but decreased to the lowest value at the stage when the seed began to mature. The researchers reported that the total flavonoid content ranged from $0.10 \mathrm{mg} \mathrm{CE} \mathrm{g}^{-1}$ to $79.17 \mathrm{mg} \mathrm{CE} \mathrm{g}^{-1}$. In addition, they also reported that the differences in the total flavonoid contents of the cultivars might be caused by the genetic characteristics, ecological differences, and breeding techniques. Similar to our finding, Turgut et al. (2020) reported that the total amount of flavonoids ranged from $137.03 \mathrm{mg} \mathrm{CE} 100 \mathrm{~g}^{-1}$ to $575.32 \mathrm{mg} \mathrm{CE}$ $100 \mathrm{~g} \mathrm{~g}^{-1}$. Tanwar and Modgil (2012) have stated that flavonoids constitute the most common group of plant polyphenols, and they give taste and color to fruits and vegetables. In addition, they reported that more than five thousand flavonoids had been identified so far, and they were separated into six subgroups, including flavonols, flavanones, flavones, flavanols, flavone-3-ols, and isoflavones. In recent years, they have stated that flavonoids have aroused great interest due to their potential beneficial effects on human health, but they also have antiviral, anti-allergic, antiplatelet, anti-inflammatory, antitumor, and antioxidant effects. 
As a result, the developmental and biochemical properties of some pecan nut cultivars that could have commercial importance in Turkey were determined with this study. With the results of the research, the importance of pecan nut, which is a food source that can reach significant levels in our country, has been emphasized. In the study, Burkett, Choctaw, Mahan, Western, and Wichita cultivars registered by the Western Mediterranean Agricultural Research Institute (BATEM) were emphasized, and the differences between the cultivars were revealed. In comparison to the other hard-shelled fruits, the high biochemical contents of pecan nuts, their high amount of calories, their easier cultivation, their better storage possibilities, and the increasing demands for them are considered as indicators that pecan nuts will gain more importance in our country. It is thought that this study will contribute to the missing literature knowledge in the pecan nut fruit.

\section{References}

Alasalvar, C., \& Bolling, B. W. (2015). Review of nut phytochemicals, fat-soluble bioactives, antioxidant components and health effects. British Journal of Nutrition, 113(2), 68-78.

Baydar, H., \& Erbas, S. (2014). Yağ bitkileri bilimi ve teknolojisi. SDÜ Yayınları, Yayın no: 97, Isparta.

Bayrakli, F. (1987). Toprak ve bitki analizleri. On Dokuz Mayıs Üniversitesi Ziraat Fakültesi Yayınları 133-134, Samsun.

Bremner, J. M. (1965). Total nitrogen, inorganic forms of nitrogen. In: Black, C. A., Evans, D. D., White J. L. (Eds.), Methods of Soil Analysis. American Society of Agronomy, Madison, WI; Agronomy, 9 (2), 1149-1237.

Rosa, L. A., Vazquez-Flores, A. A., Alvarez-Parrilla, E., Rodrigo-Garcia, J., Medina-Campos, O. N., Ávila-Nava, A., Gonzalez-Reyes, S., \& Pedraza-Chaverri, J. (2014). Content of major classes of polyphenolic compounds, antioxidant, antiproliferative, and cell protective activity of pecan crude extracts and their fractions. Journal of Functional Foods, 7, 219- 228.

Elmore, C. D., \& Polles, S. G. (1980). Nitrogen fertilization effects on amino acid composition of pecan (Carya illinoinensis) nutmeats. Journal of Agricultural and Food Chemistry, 28(5), 902-904.

Erbas, S., Tonguç, M., \& Şanl1, A. (2016). Variations in the agronomic and quality charactistics of dometic and foreign safflower Carthamus tinctorius L. genotypes. Turkish Journel of Field Crops, 21, 110-119.

Flores-Estrada, R. A., Gámez-Meza, N., Medina-Juárez, L. A., Castillón-Campaña, L. G., MolinaDomínguez, C. C., Rascón-Valenzuela, L. A., \& García-Galaz, A. (2020). Chemical composition, antioxidant, antimicrobial and antiproliferative activities of wastes from pecan nut [Carya illinoinensis (Wagenh) K. Koch]. Waste and Biomass Valorization, 11(7), 3419-3432.

Gardea, A. A., Martínez-Téllez, M. A., \& Yahia, E. M. (2011). Pecan (Carya illinoinensis (Wangenh.) K. Koch.). In Postharvest biology and technology of tropical and subtropical fruits (pp. 143166e). Woodhead Publishing.

Heerema, R. J., Wells, M. L., Lombardini, L., Nesbitt, M., Warren, C., Pegg, R. B., \& Gong, Y. (2014). Pecan kernel antioxidant capacity and oil composition are affected by mechanical pruning and by nut position in tree canopy. In XXIX International Horticultural Congress on Horticulture: Sustaining Lives, Livelihoods and Landscapes (IHC2014) 1120 (pp. 499-506).

INC, (2018). Pecan roundtable. XXXVII World Nut and Dried Fruit Congress. May 21-23, Spain. pp. 5.

Jia, X., Luo, H., Xu, M., Zhai, M., Guo, Z., Qiao, Y., \& Wang, L. (2018). Dynamic changes in phenolics and antioxidant capacity during pecan (Carya illinoinensis) kernel ripening and its phenolics profiles. Molecules, 23(2), 435.

Kacar, B., \& Inal, A. (2008). Plant analysis. Nobel Pres 1241, 891.

Kim, D. O., Jeong, S. W., \& Leea, C. Y. (2003). Antioxidant capacity of phenolic phytochemicals from various cultivars of plums. Food Chemistry 81, 321-326.

Kornsteiner, M., Wagner, K. H., \& Elmadfa, I. (2006). Tocopherols and total phenolics in 10 different nut types. Food chemistry, 98(2), 381-387.

Kumaran, A., \& Karunakaran, R. J. (2006). Antioxidant and free radical scavenging activity of an aqueous extract of Coleusa romaticus. Food Chemistry, 97, 109-114.

Lombardini, L., Restrepo-Diaz, H., \& Volder, A. (2009). Photosynthetic light response and epidermal characteristics of sun and shade pecan leaves. Journal of the American Society for Horticultural Science, 134(3), 372-378. 
Medina-Juarez, L. A., Molina-Quijada, D. M. A., Agustin-Salazar, S., Valenzuela, L. R., MolinaDomínguez, C. C., \& Gamez-Meza, N. (2018). Chemical evaluation and antioxidant capacity of Western and Wichita pecan nut cultivars [Carya illinoinensis (Wangenh.) K. Koch]. Rivista Italiana delle Sostanze Grasse, 111-118.

Mertens-Talcott, S. U., \& Percival, S. S. (2005). Ellagic acid and quercetin interact synergistically with resveratrol in the induction of apoptosis and cause transient cell cycle arrest in human leukemia cells. Cancer Letters 218, 141-151.

Ortiz-Quezada, A. G., Lombardini, L., \& Cisneros-Zevallos, L. (2011). Antioxidants in pecan nut cultivars [Carya illinoinensis (Wangenh.) K. Koch]. In Nuts and Seeds in Health and Disease Prevention (pp. 881-889). Academic Press.

Ozdemir, M. (2013). Pikan cevizi yetiştiriciliğinin Dünya'da ve Türkiye'deki yeri önemi. http://www.batem.gov.tr/haber/haftalar/ceviz/dunya ve turkiye.pdf. Erişim tarihi: 10.04.2013.

Ozer, E. A., \& Güven, A. (2008). Sert kabuklu meyvelerin săgllk üzerine etkileri (Türkiye). Türkiye 10. G1da Kongresi 21-23 May1s 2008, Erzurum, 325-326.

Poletto, T., Poletto, I., Silva, L. M. M., Muniz, M. F. B., Reiniger, L. R. S., Richards, N., \& Stefenon, V. M. (2020). Morphological, chemical and genetic analysis of southern Brazilian pecan (Carya illinoinensis) accessions. Scientia Horticulturae, 261, 108863.

Prado, A. C., Monalise Aragão, A., Fett, J. M., \& Block, R. (2009). Antioxidant properties of pecan nut [Carya illinoinensis (Wangenh.) C. Koch] shell infusion. Grasas y Aceites, 60(4), 330-335

Prado, A. C. P., Manion, B. A., Seetharaman, K., Deschamps, F. C., Arellano, D. B., \& Block, J. M. (2013). Relationship between antioxidant properties and chemical composition of the oil and the shell of pecan nuts [Carya illinoinensis (Wangenh) C. Koch]. Industrial Crops and Products, 45, 64-73.

Robbins, K. S., Gong, Y., Wells, M. L., Greenspan, P., \& Pegg, R. B. (2015). Investigation of the antioxidant capacity and phenolic constituents of US pecans. J. of Functional Foods, 15, 11-22.

Rosa, L. A., Alvarez-Parrilla, E., \& Shahidi, F. (2011). Phenolic compounds and antioxidant activity of kernels and shells of Mexican pecan (Carya illinoinensis). Journal of Agricultural and Food Chemistry, 59(1), 152-162.

Singleton, V. L., \& Rossi, J. A. (1965). Colorimetry of total phenolics with phosphomolybdic phosphotungstic acid reagents. American Journal of Enologyand Viticulture, 16(3), 144-158.

Sen, S. M. (1980). Studies on breeding by selection of walnuts of North East Anatolia and Black Sea Region. Ataturk University Agricultural Faculty Erzurum (In Turkish.)

Tanwar, B., \& Modgil, R. (2012). Flavonoids: Dietary occurrence and health benefits. Spatula Dd, 2(1), 59-68.

Turgut, D. Y., Özdemir, M., Seçmen, T., \& Çınar, O. (2020). Antalya ilinde yetiştirilen bazı pikan cevizi [Carya illinoinensis (Wangenh.) K. Koch] çeşitlerinin antioksidan özellikleri. Anadolu Tarım Bilimleri Dergisi 35(3), 526-533.

Tuzcu, Ö., \& Yıldırım, B. (2000). Pecan (Carya illinoinensis Koch) and breeding. The Scientific and Technological Research Council of Turkey, 29.

Venkatachalam, M., Kshirsagar, H. H., Seeram, N. P., Heber, D., Thompson, T. E., Roux, K. H., \& Sathe, S. K. (2007). Biochemical composition and immunological comparison of select pecan [Carya illinoinensis (Wangenh.) K. Koch] cultivars. Journal of Agricultural and Food Chemistry, 55(24), 9899-9907.

Villarreal-Lozoya, J. E., Lombardini, L., \& Cisneros-Zevallos, L. (2007). Phytochemical constituents and antioxidant capacity of different pecan [Carya illinoinensis (Wangenh.) K. Koch] cultivars. Food Chemistry, 102, 1241-1249.

Wakeling, L. T., Mason, R. L., D'Arcy, B. R., \& Caffin, N. A. (2001). Composition of pecan cultivars Wichita and Western Schley [Carya illinoinensis (Wangenh.) K. Koch] grown in Australia. Journal of Agricultural and Food Chemistry, 49(3), 1277-1281.

Zhang, C., \& Duan, Y. (2011). Performances of two species of Carya illinoinensis as "Jinhua","Shaoxing" in the Red River Area, Yunnan Province. Jiangxi Forestry Science and Technology, (2), 7. 